\title{
MECHANISM OF CHLORAMPHENICOL RESISTANCE IN BACILLUS BADIUS 211
}

\author{
Shimpei Nasu*, Yuzuru Sekine**, Kazuo Izaki and Hajime TaKahashi \\ Department of Agricultural Chemistry, Faculty of Agriculture \\ Tohoku University, Sendai, Japan
}

(Received for publication July 5, 1978)

\begin{abstract}
Six strains of chloramphenicol (CM)-resistant endospore-forming bacteria, which can grow in the presence of $100 \mu \mathrm{g} / \mathrm{ml}$ of $\mathrm{CM}$, were isolated and identified as Bacillus badius. Mechanism of CM-resistance in one of the isolated strains, Bacillus badius 211, was investigated. No inactivation of CM was demonstrated when the strain was grown in nutrient broth containing $100 \mu \mathrm{g} / \mathrm{ml}$ of $\mathrm{CM}$, as evidenced by paper-disc bioassay of $\mathrm{CM}$ in the growth medium. In accordance with this result, no CM acetylation activity was demonstrated either with the intact cells or with the crude extracts of the CM-resistant strain. Poly U- and Poly A-directed polyphenylalanine and polylysine syntheses by S-30 preparations of both CM-resistant and CM-sensitive strains of Bacillus badius were almost equally inhibited by CM. From these results, the mechanism of CM resistance in Bacillus badius 211 seems to be due to other unknown mechanism.
\end{abstract}

The mechanism of chloramphenicol (CM)-resistance in R-factor bearing Escherichia coli and other enteric bacteria, as well as in plasmid bearing Staphylococcus aureus has been shown to be inactivation of $\mathrm{CM}$ by $\mathrm{CM}$-acetyltransferase. ${ }^{1 \sim 8)}$ Other mechanisms of $\mathrm{CM}$ resistance, such as decreased membrane permeability of CM, have been postulated both in E. coli and in Pseudomonas. ${ }^{9,101}$ On the other hand, there has been no report to our knowledge, of CM-resistant Bacillus found in nature. We have isolated several strains of endospore forming and CM-resistant bacteria from soil and studied the mechanism of $\mathrm{CM}$ resistance in these bacteria.

\section{Materials and Methods}

\section{Bacterial strains}

Bacillus badius Nos. 17, 28, 37, 43, 211, and Q, which were isolated as CM-resistant bacteria from soil, were used. Bacillus badius 11059, which was kindly supplied from the Institute of Applied Microbiology, University of Tokyo, was used as a CM-sensitive strain. A CM-sensitive strain of E. coli $\mathrm{W} 2252$ was used for the bioassay of $\mathrm{CM}$ and R-factor bearing E. coli $\mathrm{W} 2252 \mathrm{R}$ was also used as a CM-resistant strain.

Media and growth conditions

The organisms were usually grown at $30^{\circ} \mathrm{C}$ with shaking in nutrient broth $(\mathrm{pH} 7.2)$ containing $1 \%$ Polypeptone (Daigo Eiyo Kagaku Co., Ltd., Osaka), 1 \% meat extract (Kyokuto Seiyaku Co., Ltd., Tokyo) and $0.5 \% \mathrm{NaCl}$. Nutrient agar medium was prepared by adding $1.5 \%$ agar to the nutrient broth.

Chemicals

Chloramphenicol (CM) was a product of the Sankyo Co., Ltd., Tokyo. D-Threo (dichloroacetyl$1-{ }^{14} \mathrm{C}$ ) chloramphenicol was purchased from the Radiochemical Centre, Amersham, England. The antibiotics thiophenicol, leucomycin, lincomycin, erythromycin, thiopeptin and mikamycin B were

* Present address: Nakano Health Center, Nakano, Tokyo

** Present address: Central Research Institute, Nihon Roche Co., Kamakura 
kindly supplied by the Eizai Co., Ltd., Tokyo, the Tōyō Jōzō Co., Ltd., Shizuoka, Kyōwa Hakko Kōgyō Co., Ltd., Tokyo, the Shionogi Seiyaku Co., Ltd., Osaka, the Fujisawa Yakuhin Co., Ltd., Osaka and the Kanegafuchi Kagaku Co., Ltd., Osaka, respectively.

Isolation of endospore-forming CM-resistant bacteria

Samples taken from the soil surface and from a depth of about $10 \mathrm{~cm}$ underground were suspended in $6 \mathrm{ml}$ of distilled water and heated at $80^{\circ} \mathrm{C}$ for 30 minutes to select spore-forming bacteria. Then, the suspensions were diluted, plated out on nutrient agar containing $50 \mu \mathrm{g} / \mathrm{ml}$ of $\mathrm{CM}$, and incubated at $37^{\circ} \mathrm{C}$ for 4 days. The colonies formed on the plates were isolated and purified on nutrient agar with and without $50 \mu \mathrm{g} / \mathrm{ml}$ of $\mathrm{CM}$.

Determination of minimal inhibitory concentration of various antibiotics

Overnight cultures of isolated bacteria were inoculated into $6 \mathrm{ml}$ of fresh nutrient broth containing various concentrations of antibiotics, adjusting the O.D. at $660 \mathrm{~nm}$ to about 0.1 , and the cultures were incubated at $37^{\circ} \mathrm{C}$ with shaking for 10 hours. Bacterial growth was measured by O.D. determinations at $660 \mathrm{~nm}$ using a Hitachi photoelectric colorimeter (FPW-4) and growth inhibitory concentrations of various drugs were determined.

Quantitative analysis of chloramphenicol concentration in the growth medium

The concentration of $\mathrm{CM}$ in the medium during bacterial growth was measured by paper-disc bioassay using E. coli W 2252 as a test strain. Six milliliters of overnight culture of B. badius 211 were inoculated into $100 \mathrm{ml}$ of fresh nutrient broth containing $100 \mu \mathrm{g} / \mathrm{ml}$ of CM and incubated at $37^{\circ} \mathrm{C}$ with shaking for 40 hours. Five milliliters of the culture were taken at various incubation time periods and heated at $95^{\circ} \mathrm{C}$ for 3 minutes. After the cells were removed by centrifugation at $12,000 \times g$ for 5 minutes, the concentration of CM in the supernatant was determined by paper-disc bioassay.

Radioisotope assay of chloramphenicol acetylating activity in vivo and in vitro

In vivo assay: Overnight culture in nutrient broth was inoculated into $6 \mathrm{ml}$ of fresh nutrient broth containing about 0.32 nmole $(600,000 \mathrm{dpm})$ of ${ }^{14} \mathrm{C}$-chloramphenicol; the O.D. was adjusted at $660 \mathrm{~nm}$ to 0.2 . The cells were grown at $37^{\circ} \mathrm{C}$ with shaking until the optical density of the culture reached 1.0. The cells were then removed by centrifugation at $12,000 \times g$ for 5 minutes, and to the supernatant an equal volume of cold ethyl acetate was added. The mixture was agitated by means of a Vortex mixer for 1 minute, and the upper layer was removed after clarification by low speed centrifugation. The extraction procedure was repeated once more. The combined ethyl acetate fractions were pooled and concentrated using an evaporator (Model TC-8 Taiyō Kagaku Co., Ltd.,) under reduced pressure. The residue was then dissolved in $20 \mu \mathrm{l}$ of ethyl acetate and the solution spotted on Tōyō Filter paper No. 51 A. The paper was developed with benzene-methanol - water (98:2:2, upper phase) for about 3 hours. ${ }^{14} \mathrm{C}$-Chloramphenicol and its acetylated products were located by radioautography, using a Fuji X-ray film. Areas of the paper corresponding to radioactive compounds were cut out, placed in vials and counted in a liquid scintillation spectrometer (Packard Tri-Carb Model 3385) using a scintillation fluid composed of $4 \mathrm{~g}$ of 2.5-diphenyloxazole in 1 liter of toluene.

In vitro assay: Enzymatically formed acetyl derivatives of $\mathrm{CM}$ were assayed according to the method described previously ${ }^{111}$ with slight modification. The assay was performed on a reaction mixture which contained $10 \mu$ moles of Tris- $\mathrm{HCl}$ buffer (pH 7.8), $8 \mu$ moles of acetyl CoA, and 3.0 nmoles $\left(5.3 \times 10^{4} \mathrm{dpm}\right)$ of ${ }^{14} \mathrm{C}$-chloramphenicol in a total volume of $40 \mu \mathrm{l}$. The reaction was initiated by adding $40 \mu \mathrm{l}$ of enzyme preparation (70 80 $\mu \mathrm{g}$ protein), and the mixture was incubated at $37^{\circ} \mathrm{C}$ for 30 minutes. The reaction was terminated by heating at $95^{\circ} \mathrm{C}$ for 10 minutes. The reaction mixture was extracted twice with $100 \mu$ l of cold ethyl acetate. Separation of acetylated CM from CM by paper chromatography and counting of radioactivity were carried out in the same way as in the in vivo assay.

Preparation of cell-free extracts for assay of CM-acetylating activity

The cells were grown in nutrient broth to an O.D. of $c a$. 0.8 , harvested by centrifugation, and washed twice with $0.02 \mathrm{M}$ Tris- $\mathrm{HCl}$ buffer $\left(\mathrm{pH} 7.8\right.$ ) containing $0.06 \mathrm{M} \mathrm{KCl}, 0.01 \mathrm{M} \mathrm{MgSO}_{4}$ and $0.006 \mathrm{M}$ 2-mercaptoethanol. The washed cells were finally suspended in 10 volumes of the same buffer and 
sonicated at $10 \mathrm{KHz}$ for 10 minutes using a sonic oscillator (Kubota Seisakujo Co., Ltd., Tokyo). The supernatant obtained by centrifugation of the sonicate at $24,000 \times g$ for 30 minutes was dialyzed for 24 hours at $4^{\circ} \mathrm{C}$ against 20 volumes of the same buffer with 3 changes of the buffer. The cell-free extracts were stored at $-80^{\circ} \mathrm{C}$ until used.

\section{Preparation of S-30 fraction}

Bacteria were grown at $37^{\circ} \mathrm{C}$ with shaking in nutrient broth enriched with $0.2 \%$ yeast extract. The cells in their logarithmic growth phase (O.D. at $660 \mathrm{~nm} 0.4 \sim 0.6$ ) were harvested by centrifugation and washed twice with cold buffer $(0.01 \mathrm{M}$ Tris- $\mathrm{HCl}$ buffer $\mathrm{pH} 7.8,0.01 \mathrm{M}$ magnesium acetate, $0.06 \mathrm{M}$ $\mathrm{KCl}$ and $0.006 \mathrm{M}$ mercaptoethanol). The cells were finally suspended in 3 volumes of the same buffer, and disrupted in a French pressure cell (Model 5615, Ohtake Seisakujo Co., Ltd., Tokyo) at 400 $500 \mathrm{~kg} / \mathrm{cm}^{2}$ and $0^{\circ} \mathrm{C}$. DNase was added to the cell homogenates at the concentration of $20 \mu \mathrm{g} / \mathrm{ml}$, and the mixture centrifuged three times: $15,000 \times g$ for 10 minutes, $20,000 \times g$ for 20 minutes and $30,000 \times g$ for 30 minutes. The pellets were discarded after each centrifugation. The final supernatant (S-30) was dialyzed for 24 hours at $4^{\circ} \mathrm{C}$ against 30 volumes of the same buffer and stored frozen at $-80^{\circ} \mathrm{C}$.

Conditions for amino acid incorporation

Reaction mixtures contained the following components: Tris- $\mathrm{HCl} \mathrm{pH} \mathrm{8.0,} 40 \mu$ moles; magnesium acetate, $10 \mu$ moles; $\mathrm{NH}_{4} \mathrm{Cl}, 40 \mu$ moles; GTP (Na-salt), $0.2 \mu$ moles; ATP (Na-salt), $0.8 \mu$ moles; phosphoenolypyruvate (K-salt), $4.0 \mu$ moles; mercaptoethanol, $40 \mu$ moles; spermidine, $0.8 \mu$ moles; ${ }^{3} \mathrm{H}$-phenylalanine or ${ }^{3} \mathrm{H}$-lysine $(0.5 \mu \mathrm{Ci}), 1.5 \mathrm{nmoles}$; pyruvate kinase, $10 \mu \mathrm{g}$; t-RNA, $600 \mu \mathrm{g}$; polyU or polyA, $50 \mu \mathrm{g}$; and S-30 preparation, $200 \mu \mathrm{l}$ (3.0 4.0 mg protein); total volume: $1 \mathrm{ml}$. The reaction mixture containing all the components except the S-30 preparation was preincubated at $37^{\circ} \mathrm{C}$ for 5 minutes. The reaction was started by adding $200 \mu \mathrm{l}$ of S-30 preparation. The mixture was incubated for 30 minutes and the reaction terminated by the addition of $1 \mathrm{ml}$ of $10 \%$ trichloroacetic acid (TCA). The precipitates were washed twice with $2 \mathrm{ml}$ of $5 \% \mathrm{TCA}$, heated at $90^{\circ} \mathrm{C}$ for 15 minutes in $2 \mathrm{ml}$ of $5 \% \mathrm{TCA}$, washed successively with $95 \%$ ethanol, ethanol-ether (1:1), and ether. The washed precipitates were dried at $30^{\circ} \mathrm{C}$, then solubilized in $1 \mathrm{ml}$ of $5 \%$ sodium dodecyl sulfate solution at $37^{\circ} \mathrm{C}$. Radioactivity of the sample was counted in the liquid scintillation spectrometer using a toluene-Nonione scintillation fluid, from which POPOP was omitted. ${ }^{121}$

\section{Results}

\section{Isolation and Identification of CM-resistant Bacteria}

Six strains of endospore-forming, CM-resistant bacteria (strains 17, 28, 37, 43, 211 and Q) were isolated from soil sampled in the Miyagi Prefecture. These bacteria were resistant to more than $50 \mu \mathrm{g} / \mathrm{ml}$ of CM. Taxonomical characteristics of these bacteria are reported in Table 1; all six strains were identified as Bacillus badius. One of these strains, Bacillus badius 211, was mainly used in the following experiments.

Minimal Inhibitory Concentrations of Various Antibiotics for Isolated Bacteria

Minimal inhibitory concentrations of various antibiotics including CM were determined for strains 211 and 11059 (sensitive control). Results are shown in Table 2. In this experiment, antibiotics, known as inhibitors of protein synthesis in bacteria, were used. B. badius 211 was resistant to more than $100 \mu \mathrm{g} / \mathrm{ml}$ of $\mathrm{CM}$ and thiophenicol. This strain was sensitive to streptomycin (SM), kanamycin (KM), and tetracycline (TC) at concentrations lower than $5 \mu \mathrm{g} / \mathrm{ml}$; these antibiotics are inhibitors of the 30-S subunit of the ribosome. ${ }^{13)}$ On the other hand, strain 211 was resistant to some of the antibiotics which are inhibitors of the 50-S subunit, such as spiramycin, erythromycin, lincomycin and mikamycin B. ${ }^{13)}$ This strain, however, was sensitive to low concentrations of leucomycin and thiopeptin. CM-sensitive B. badius 11059 was sensitive to all antibiotics at con- 
Table 1. Taxonomical characteristics of isolated CM-resistant bacteria

\begin{tabular}{c|c}
\hline Rods: Width, $\mu \mathrm{m}$ & $0.5 \sim 0.7$ \\
Length, $\mu \mathrm{m}$ & $1.5 \sim 3.0$ \\
Spore: Shape & Elliptical \\
Position & Central \\
Distension of sporangium & None \\
Acid from: Glucose & - \\
$\quad$ Xylose & - \\
$\quad$ Arabinose & - \\
Glucose & - \\
Xylose & - \\
$\quad$ Mannose & - \\
Acetoin from glucose & - \\
Hydrolysis of starch & + \\
Deamination of phenylalanine & - \\
Growth in $7 \%$ NaCl & + \\
Reduction of NO ${ }_{3}^{-}$to NO ${ }_{2}^{-}$ & - \\
Uric acid utilization & - \\
G+C content of DNA, $\%$ & 44 \\
\hline
\end{tabular}

Isolated strains were designated 17, 28, 37, 43, 211 and Q. Position of spore and distention of sporangium were observed by phase contrast microscopy. G+C content of DNA was determined by melting temperature.
Table 2. Minimal inhibitory concentrations of various antibiotics against $B$. badius 211 and $B$. badius 11059

\begin{tabular}{l|r|r}
\hline \multirow{2}{*}{ Antibiotics } & \multicolumn{2}{|c}{$\mu \mathrm{g} / \mathrm{ml}$} \\
\cline { 2 - 3 } & B. badius 211 & B. badius 11059 \\
\hline Chloramphenicol & 100 & 10 \\
Streptomycin & 5 & 5 \\
Kanamycin & 5 & 5 \\
Tetracycline & 5 & 5 \\
Thiophenicol & 100 & 10 \\
Leucomycin & 5 & 5 \\
Spiramycin & 100 & 10 \\
Erythromycin & 100 & 10 \\
Lincomycin & 100 & 25 \\
Thiopeptin & 5 & 5 \\
Mikamycin B & 50 & 5 \\
\hline
\end{tabular}

Cells were incubated at $37^{\circ} \mathrm{C}$ for 10 hours in nutrient broth containing various concentrations of drugs and growth inhibitory concentrations were determined.

centrations lower than $10 \mu \mathrm{g} / \mathrm{ml}$ (except lincomycin).

Absence of CM Inactivation in CM-resistant Bacillus badius 211

Inactivation of CM in CM-resistant B. badius

211 during growth was examined by paper-disc bioassay. The results are shown in Fig. 1. No significant change in the concentration of CM was observed for 36 hours of incubation. R factorbearing E. coli, Pseudomonas and plasmid-bearing Staphylococcus are known to inactivate CM by chloramphenicol acetyltransferase. To examine CM-acetylating activity in CM-resistant $B$. badius 211, radioisotope assay was carried out using both intact cells (in vivo assay) and crude extracts (in vitro assay). Since CM-acetylating activity may be inducible in CM-resistant B. badius 211, the organism was grown in nutrient broth with and without $20 \mu \mathrm{g} / \mathrm{ml}$ of CM. In the case of the CMsensitive strain, B. badius 11059, the cells were grown in nutrient broth with and without $2 \mu \mathrm{g} / \mathrm{ml}$ of CM. When the reaction mixture was analyzed by paper chromatography, acetylated compounds were well separated from CM. After autoradiography, radioactivities of both acetylated and unchanged CM were counted. As shown in Table 3, approximately $90 \%$ of added CM were converted to acetylated CM, when the cells of E. coli W $2252 \mathrm{R}$ were incubated with radioactive CM, while essentially no change of CM was observed with the cells of B. badius 211 . The same results were observed with cell-free extracts. No significant $\mathrm{CM}$-acetylating activity was observed with the crude extracts from CM-resistant B. badius 211 and CM-sensitive B. badius 11059. As shown in Table 4, CM-acetylating activity was only detected in E. coli W 2252 R.

Effect of CM on Polyphenylalanine and Polylysine Syntheses by S-30 Preparation

Effect of CM on polyphenylalanine and polylysine syntheses by S-30 preparation was investigated. Fig. 2 shows the effect of $\mathrm{CM}$ on incorporation of ${ }^{3} \mathrm{H}$-phenylalanine (A) and ${ }^{3} \mathrm{H}$-lysine (B) into 
polypeptide, using S-30 preparations of both $B$. badius 211 and $B$. badius 11059 . Both syntheses were similarly affected in CM-sensitive and CMresistant strains. As reported previously, ${ }^{14)}$ inhibition of polylysine synthesis by $\mathrm{CM}$ is more marked than that of polyphenylalanine synthesis.

\section{Discussion}

Two major types of mechanism of $\mathrm{CM}$ resistance in bacteria have been reported. One is inactivation of $\mathrm{CM}$ by $\mathrm{CM}$ acetyltransferase in R-factor-bearing enteric bacteria and plasmidbearing Staphylococcus, ${ }^{1,3 \sim 6)}$ the other is decreased permeability of bacteria to $\mathrm{CM}^{9,10)}$. In our isolated $B$. badius 211, neither inactivation nor acetylation of CM were demonstrated by either bioassay or radioisotope assay. When we examined the effect of CM on polyphenylalanine and polylysine syntheses using S-30 preparations of both CM-sensitive and CM-resistant strains of B. badius, only a slight difference in CM sensitivity was found between these two strains. There is a possibility that the resistant strain of $B$. badius excreted antagonists of $\mathrm{CM}$ into the medium and therefore was resistant to CM. This possibility, however, can be ruled out because the sensitive strain of $B$. badius could not grow in nutrient broth containing $50 \mu \mathrm{g} / \mathrm{ml}$ of $\mathrm{CM}$ in which the resistant strain of $B$. badius had been pregrown for more than 20 hours. From these results, it is concluded that the mechanism of CM resistance in B. badius 211 is neither inactivation of $\mathrm{CM}$ nor the presence of CM-resistant protein synthesis, but is due to an unknown factor, probably the impossibility of $\mathrm{CM}$ to reach the target site. Although we have examined the uptakes of ${ }^{14} \mathrm{C}$-chloramphenicol by the cells of both sensitive and resistant strains, we have not yet obtained reliable data, probably due to technical difficulty. As shown in Table 1, this resistant strain of $B$. badius was also resistant to various antibiotics, such as erythromycin, spiramycin,

Table 3. CM-acetylating activities of CM-resistant E. coli $\mathrm{W} 2252$ and B. badius 211

\begin{tabular}{c|c|c}
\hline \multirow{2}{*}{ Strain } & \multicolumn{2}{|c}{ Radioactivity (dpm) } \\
\cline { 2 - 3 } & CM & $\begin{array}{c}\text { Acetylated } \\
\text { CM }\end{array}$ \\
\hline B. badius 211 & & \\
Pregrown with CM & 54890 & 170 \\
Pregrown without CM & 53240 & 260 \\
E. coli W 2252 R & & \\
Pregrown with CM & 8540 & 49130 \\
Pregrown without CM & 8640 & 53430 \\
Minus cells & 40910 & 280 \\
\hline
\end{tabular}

Cells of $B$. badius 211 and $E$. coli W $2252 \mathrm{R}$ were grown in nutrient broth containing radioactive $\mathrm{CM}$ for 5 7 hours to reach an O.D. of 1.0. Then, the supernatant obtained by centrifugation was extracted with ethyl acetate, and analyzed for the formation of acetylated chloramphenicol.
Table 4. CM-acetylating activities of various strains of bacteria

\begin{tabular}{l|c|c}
\hline \multirow{2}{*}{ Strain } & \multicolumn{2}{|c}{ Radioactivity (dpm) } \\
\cline { 2 - 3 } & CM & $\begin{array}{c}\text { Acetylated } \\
\text { CM }\end{array}$ \\
\hline $\begin{array}{l}\text { E. coli } \text { W 2252 R } \\
\text { B. badius 211 }\end{array}$ & 43800 & 4580 \\
Pregrown with CM & 42620 & 80 \\
Pregrown without CM & 27930 & 80 \\
B. badius 11059 & 40410 & 60 \\
Pregrown with CM \\
Pregrown without CM & 31490 & 80 \\
\hline
\end{tabular}

Crude extracts were prepared from the cells of $E$. coli W 2252 R (non-induced), B. badius 211 and $B$. badius 11059 (induced and non-induced). CMacetylating activities of these crude extracts were assayed. 
Fig. 2. (A) Effect of chloramphenicol on incorporation of ${ }^{3} \mathrm{H}$-phenylalanine into polypeptide by S-30 preparation.

S-30 preparations were prepared from the cells of both $B$. badius 11059 (CM-sensitive strain) and B. badius 211 (CM-resistant strain) and the effects of $\mathrm{CM}$ on polyphenylalanine syntheses by these S-30 preparations were examined.

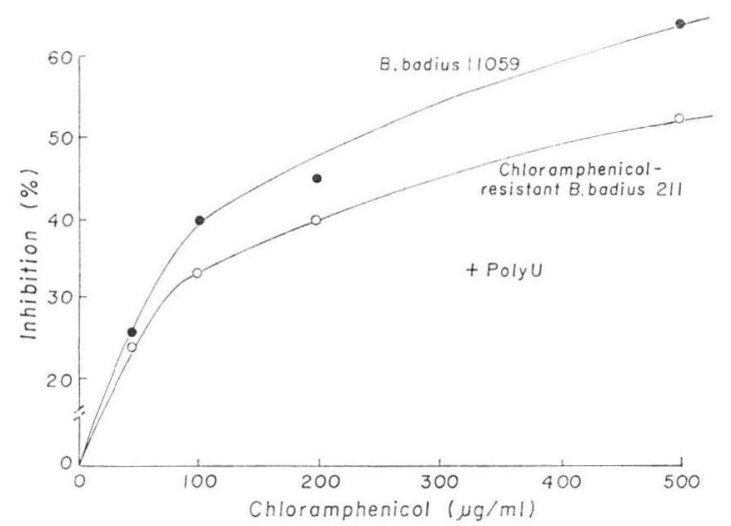

Fig. 2. (B) Effect of chloramphenicol on incorporation of ${ }^{3} \mathrm{H}$-lysine into polypeptide by $\mathrm{S}-30$ preparation.

S-30 preparations were prepared from the cells of both $B$. badius 11059 (CM-sensitive strain) and $B$. badius 211 (CM-resistant strain) and the effects of $\mathrm{CM}$ on polylysine syntheses by these S-30 preparations were examined.

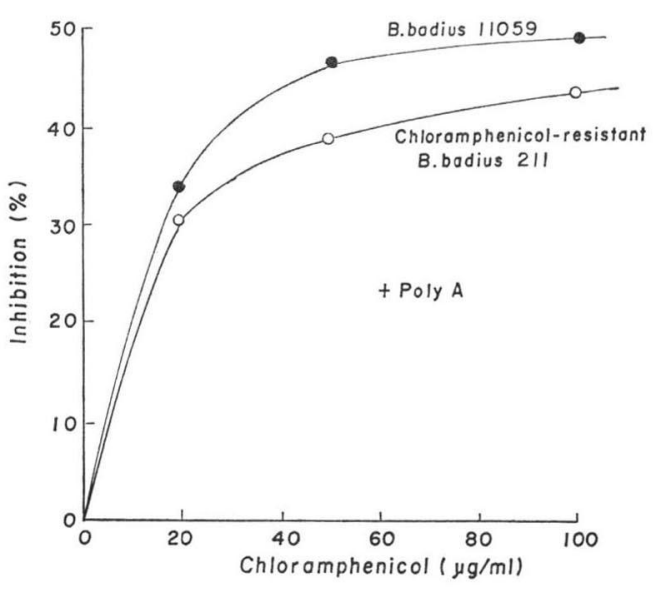

lincomycin and mikamycin. We have obtained a partially CM-sensitive mutant from CM-resistant parent strain, $B$. badius 211 , by nitrosoguanidine treatment. This strain, however, retained a similar level of erythromycin resistance to that of the parent strain. Therefore, the factor determining erythromycin resistance seems to be different from that of $\mathrm{CM}$ resistance in this parent strain. Inactivation of erythromycin has not been demonstrated in this resistant strain.

\section{Acknowledgement}

We thank Miss K. SaIto and Miss A. SAto of this Faculty for their help in the radioassays.

\section{References}

1) Окамото, S. \& Y. SuzUKI: Chloramphenicol-, dihydrostreptomycin- and kanamycin-inactivating enzymes from multiple drug resistant Echerichia coli carrying episome 'R'. Nature 208: 1301 1303, 1965

2) Umezawa, H.; M. Okanishi, S. Kondo, K. Hamana, R. Utahara, K. Maeda \& S. Mitsuhashi: Phosphorylative inactivation of aminoglycosidic antibiotics by Escherichia coli carrying R-factor. Science 157: 1559 1561, 1967

3) SHAw, W. V.: The enzymatic acetylation of chloramphenicol by extracts of R factor resistant Escherichia coli. J. Biol. Chem. 242: 687 693, 1967

4) SuzuKi, Y. \& S. Окамото: The enzymatic acetylation of chloramphenicol by the multiple drugresistant Escherichia coli carrying R factor. J. Biol. Chem. 242: 4722 4730, 1967

5) SHAW, W. V. \& R. F. BRoDsky: Characterization of chloramphenicol acetyltransferase from chloramphenicol-resistant Staphylococcus aureus. J. Bact. 95: 28 36, 1968

6) WinSHeLl, E. \& W. V. SHAW: Kinetics of induction and purification of chloramphenicol-acetyltransferase from chloramphenicol-resistant Staphylococcus aureus. J. Bact. 98: 1248 1257, 1969

7) Kono, M.; K. Ogawa \& S. Mitsuhashi: Drug resistance of Staphylococci. VI. Genetic determinant for chloramphenicol resistance. J. Bact. 95: 886 892, 1968

8) Iyobe, S.; M. Kono, K. O'Hara, H. Hashimoto \& S. Mitsuhashi: Relationship between chloramphenicol acetyltransferase activity and number of resistance genes. Antimicr. Agents \& Chemoth. 5: 68 74, 1974 
9) Kono, M. \& K. O'HARA: Mechanism of chloramphenicol resistance mediated by KR 102 factor in Pseudomonas aeruginosa. J. Antibiotics 29: 176 180, 1976

10) Nagai, Y. \& S. Mitsuhashi: New type of R factors incapable of inactivating chloramphenicol. J. Bact. 109: 1 7, 1972

11) TANaKa, H.; K. IzaKi \& H. TAKahashi: Some properties of chloramphenicol acetyltransferase, with particular reference to mechanism of inhibition by basic triphenylmethane dyes. J. Biochem. 76: 1009 1019, 1974

12) Kawakami, M. \& K. Shimura: A new scintillator in liquid scintillation counting and simplified method of sample preparation for determination of tritium or carbon 14. Radioisotope 23: 81 87, 1974

13) Weisblum, B. \& J. Davis: Antibiotic inhibitors of the bacterial ribosome. Bacteriol Rev. 32: 493 528,1968

14) Speyer, J. F.; P. Lengyel, C. Basilio, A. J. Wahba, R. S. Gardner \& S. Ochoa: Synthetic polynucleotides and the amino acid code. Cold Spring Harbor Symposia Quant. Biol. 28: 559 567, 1963 